\title{
Stubble catch crops cultivated in accordance with the principles of agri-environmental scheme "Soil and water protection" as a plant-health factor in spring wheat
}

\author{
Międzyplony ścierniskowe uprawiane zgodnie \\ z zasadami programu rolnośrodowiskowego „Ochrona gleb i wód” \\ jako czynnik fitosanitarny w pszenicy jarej
}

\author{
Wiesław Wojciechowski*, Martyna Szałata, Anna Lehmann
}

\begin{abstract}
Summary
The experiment was conducted in 2011-2012 at the Agricultural Experiment Station Swojec that belongs to Wroclaw University of Environmental and Life Sciences. The purpose of this study was to determine the impact of stubble catch crop, its spring arrangement and nitrogen fertilization on plant-health factor of spring wheat. Beneficial influence of white mustard and stubble catch crop as a mixture of pulse crops on health status of spring wheat culms and roots compared to a crop without stubble catch crop was shown. White mustard catch crop improved health status of plants more than other stubble catch crops. Infection index of spring wheat after spring ploughing or disk harrow catch crop biomass was smaller than in the direct seeding in mulch. Health status of wheat was better after reduction of nitrogen fertilizer doses. Infection index of roots was the lowest in spring cultivated after mixture stubble catch crop as a mixture of pulse crops, with spring disking its biomass and half reduction the nitrogen fertilization, the highest was after direct seeding, without stubble catch crop and with full dose of nitrogen fertilizer.
\end{abstract}

Key words: health status; spring wheat; stubble catch crop; tillage system; nitrogen fertilization

\section{Streszczenie}

Badania przeprowadzono w latach 2011-2012 w Rolniczym Zakładzie Doświadczalnym Swojec, należącym do Uniwersytetu Przyrodniczego we Wrocławiu. Celem eksperymentu było określenie oddziaływania międzyplonu ścierniskowego, jego wiosennego zagospodarowania i nawożenia azotem na zdrowotność pszenicy jarej. Wykazano korzystny wpływ międzyplonów ścierniskowych zarówno z gorczycy, jak i mieszanki roślin strączkowych na zdrowotność korzeni i źdźbeł pszenicy jarej w porównaniu z uprawą bez międzyplonu. Lepszą okazała się gorczyca biała. Indeks porażenia pszenicy jarej po wiosennym przyoraniu lub talerzowaniu biomasy międzyplonu był znacznie mniejszy niż w siewie bezpośrednim w mulcz. Redukcja dawki nawożenia azotowego poprawiła zdrowotność roślin pszenicy, co szczególnie widoczne było w indeksie porażenia źdźbeł. Zauważono istotne oddziaływanie współdziałania wszystkich czynników na zdrowotność korzeni rośliny uprawnej. Korzenie z najmniej widocznymi objawami chorobowymi stwierdzono w uprawie pszenicy po międzyplonie z mieszanki roślin strączkowych, jego wiosennym talerzowaniu i stosowaniu połowy dawki nawożenia $\mathrm{N}$, a najbardziej widoczne objawy występowały w siewie bezpośrednim, bez międzyplonu i przy pełnej dawce azotu.

Słowa kluczowe: zdrowotność; pszenica jara; międzyplon ścierniskowy; sposób uprawy; nawożenie azotem

Uniwersytet Przyrodniczy we Wrocławiu

Katedra Kształtowania Agroekosystemów i Terenów Zieleni

PI. Grunwaldzki 24A, 50-363 Wrocław

*corresponding author: wieslaw.wojciechowski@up.wroc.pl 


\section{Wstęp / Introduction}

Jednymi z podstawowych zasad uprawy międzyplonów w programie rolnośrodowiskowym „Ochrona gleb i wód” jest wysianie ich najpóźniej do 30 września oraz wznowienie zabiegów agrotechnicznych dopiero po 1 marca. Za takie działanie rolnicy mogą otrzymać dodatkowe dopłaty.

Międzyplony ścierniskowe wpływają korzystnie na właściwości gleby, stanowiąc cenne źródło materii organicznej co jest szczególnie ważne w dobie niedoboru obornika (Wojciechowski 2008). Jaskulska i Gałęzewski (2009) twierdzą, że międzyplony ścierniskowe przez wiązanie swoim systemem korzeniowym wierzchniej warstwy gleby, przeciwdziałają erozji wodnej i wietrznej. Ten element zmianowania ogranicza często zachwaszczenie łanu (Dworakowski 1998; Wojciechowski 2009; Gawęda i Haliniarz 2013) oraz podnosi plonowanie roślin (Harasim i Gawęda 2010; Gawęda i Haliniarz 2013). Międzyplony ścierniskowe wpływają również na poprawę stanu sanitarnego rośliny uprawnej (Wojciechowski 2008). Narkiewicz-Jodko i wsp. (2008) donoszą, że mają one również istotne znaczenie w poprawie zdrowotność pozyskanego plonu.

Pozostawienie międzyplonów do wiosny wymusza opracowanie najbardziej optymalnego wiosennego wymieszania ich z glebą. Należy rozważyć, czy zastosować orkę wiosenną, która może znacznie przesuszyć warstwę orną, czy lepiej wykonać uprawę uproszczoną lub wręcz siew bezpośredni rośliny następczej w mulcz obumarłej biomasy międzyplonu. Te działania pozwolą jednocześnie na obniżenie kosztów i energii (Orzech i wsp. 2009). Arvidsson (1998) twierdzi, że uproszczenia w uprawie, a szczególnie siew bezpośredni sprzyjają występowaniu chorób podstawy źdźbła i korzeni.

Nawożenie azotem ma istotny wpływ na wysokość plonów ziarna pszenicy jarej, ale także na ich jakość. Nadmierne dawki azotu powodują obniżenie plonów, ale także mogą spowodować wyleganie roślin i zwiększyć ich podatność na choroby wywołane przez grzyby (Borkowska i wsp. 2002; Pląskowska 2005).

Celem badań było określenie oddziaływania międzyplonów ścierniskowych uprawianych zgodnie z zasadami programu rolnośrodowiskowego, sposobów ich wiosennego zagospodarowania i zróżnicowanego nawożenia azotem na indeks porażenia źdźbeł i korzeni pszenicy jarej.

\section{Materiały i metody / Materials and methods}

Badania przeprowadzono w latach 2011-2012 w Rolniczym Zakładzie Doświadczalnym Swojec, należącym do Uniwersytetu Przyrodniczego we Wrocławiu. Doświadczenie zostało założone na madzie rzecznej, klasy bonitacyjnej IVa, kompleksu żytniego dobrego. Pszenicę jarą odmiany Tybalt uprawiano po przedplonie $\mathrm{z}$ rzepaku ozimego. Eksperyment wykonano w oparciu o trzyczynnikowe doświadczenie polowe. Czynnikiem pierwszego rzędu był udział międzyplonów ścierniskowych: A1) bez międzyplonu, A2) międzyplon $\mathrm{z}$ gorczycy białej, A3) międzyplon $\mathrm{z}$ mieszanki roślin strączkowych (groch pastewny + bobik). Międzyplony uprawiane były zgodnie z zasadami programu rolnośrodowiskowego, znajdującymi się w pakiecie „Ochrona gleb i wód”. Drugi czynnik stanowiły różne sposoby wiosennego zagospodarowania międzyplonu: B1) wykorzystanie biomasy międzyplonu ścierniskowego jako mulcz - siew bezpośredni pszenicy, B2) orka, B3) talerzowanie. Trzecim czynnikiem doświadczenia było zastosowanie pełnej oraz o połowę niższej dawki azotu: C1) pełna $(1 \mathrm{~N})-120 \mathrm{~kg} / \mathrm{ha}(40 \mathrm{I}+40 \mathrm{II}+$ 40III); C2) połowa dawki $(1 / 2 \mathrm{~N})-60 \mathrm{~kg} / \mathrm{ha}(40 \mathrm{I}+20 \mathrm{II})$. Azot stosowano w trzech terminach: I - przed siewem pszenicy, II - w fazie strzelania w źdźbło (faza BBCH 3132) i III - podczas kłoszenia się roślin (faza BBCH 49).

Oceny porażenia korzeni i podstawy źdźbła dokonano w fazie dojrzałości mlecznej (BBCH 75). Do tego celu z każdego poletka pobierano po 35 roślin. Wydzielono pięć klas porażenia korzeni: 0 - zdrowe; $1-1-10 \%$ korzeni z objawami chorobowymi; $2-11-30 \%$ powierzchni korzeni porażonych; $3-31-60 \%$ powierzchni korzeni porażonych; 4 - powyżej $61 \%$ korzeni $\mathrm{z}$ widocznymi objawami chorób oraz cztery klasy porażenia podstawy źdźbła: 0 - zdrowe, 1 - infekcja na odcinku do 1. kolanka, mniej niż $1 / 2$ obwodu źdźbła zainfekowana, 2 - zakażenie na odcinku do 1 . kolanka, ponad $1 / 2$ obwodu źdźbła zainfekowana, 3 - porażenie wchodzi w kolejne międzywęźle. Indeks porażenia obliczony został na podstawie metody Townsenda-Heubergera (1943).

\section{Wyniki i dyskusja / Results and discussion}

Wykazano znaczący wpływ międzyplonów ścierniskowych na indeks porażenia podstawy źdźbła pszenicy jarej (tab. 1). Międzyplon $\mathrm{z}$ gorczycy istotnie zmniejszył porażenie o 3,4 punktów procentowych (p.p.), a $\mathrm{z}$ mieszanki o 2,1 p.p. w porównaniu do wykazanego w uprawie bez międzyplonu. Podobne wyniki uzyskał Wojciechowski (2005) wykazując, że przyoranie gorczycy poprawiło zdrowotność pszenicy o 3,4\% w porównaniu do uprawy bez międzyplonu. Również Kwiatkowski (2008) udowodnił, że gorczyca biała i mieszanka roślin strączkowych ograniczają porażenie podstawy źdźbła jęczmienia jarego. Badania własne pokazują, że rośliną międzyplonową w większym stopniu poprawiającą zdrowotność źdźbeł pszenicy jarej okazała się gorczyca biała niż mieszanka strączkowa. Również Blecharczyk i wsp. (2000) stwierdzili, że przedplon z grochu ogranicza porażenie podstawy źdźbła, liści i kłosów pszenicy ozimej po nim wysiewanej. Groch ten uprawiany był jako plon główny, a nie jako międzyplon.

Wykazano istotne oddziaływanie różnych sposobów wiosennego zagospodarowania na indeks porażenia źdźbeł. Każde wiosenne wymieszanie międzyplonu z glebą przez orkę lub talerzówkę istotnie zmniejszyło indeks porażenia, odpowiednio o 2,9 i 2,0 p.p., niż w siewie bezpośrednim w mulcz. Podobne wyniki otrzymali Faltyn i Kordas (2009), którzy wykazali, że indeks porażenia pszenicy jarej przez patogeny wywołujące choroby podstawy źdźbła zwiększył się po siewie bezpośrednim. Inne rezultaty uzyskali Bailey i wsp. (1992) oraz Weber i wsp. (2001), którzy odnotowali, że w bezorkowych systemach uprawy występowało mniejsze porażenia podstawy źdźbła i korzeni. Również 
Tabela 1. Indeks porażenia źdźbeł pszenicy jarej (2011-2012)

Table 1. Infection index of spring wheat culms (2011-2012)

\begin{tabular}{|c|c|c|c|c|c|c|}
\hline \multirow[b]{2}{*}{$\begin{array}{l}\text { Sposób uprawy } \\
\text { Tillage system }\end{array}$} & \multirow{2}{*}{$\begin{array}{l}\text { Nawożenie } \\
\text { azotem } \\
\text { Nitrogen } \\
\text { fertilization } \\
{[\mathrm{kg} / \mathrm{ha}]}\end{array}$} & \multicolumn{4}{|c|}{ Międzyplon - Catch crop } & \multirow{2}{*}{$\begin{array}{c}\text { Średnio } \\
\text { dla uprawy } \\
\text { Mean } \\
\text { for tillage }\end{array}$} \\
\hline & & $\begin{array}{c}\text { brak } \\
\text { without }\end{array}$ & $\begin{array}{l}\text { gorczyca } \\
\text { mustard }\end{array}$ & $\begin{array}{c}\text { mieszanka } \\
\text { mixture }\end{array}$ & $\begin{array}{c}\text { średnio } \\
\text { mean }\end{array}$ & \\
\hline \multirow{3}{*}{$\begin{array}{l}\text { Siew bezpośredni } \\
\text { Direct seeding }\end{array}$} & $1 / 2 \mathrm{~N}$ & 21,0 & 13,8 & 16,8 & 17,2 & \multirow{3}{*}{17,7} \\
\hline & $1 \mathrm{~N}$ & 21,1 & 16,4 & 17,0 & 18,1 & \\
\hline & $\begin{array}{c}\text { średnio } \\
\text { mean }\end{array}$ & 21,0 & 15,1 & 16,9 & - & \\
\hline \multirow{3}{*}{$\begin{array}{l}\text { Orka } \\
\text { Ploughing }\end{array}$} & $1 / 2 \mathrm{~N}$ & 12,9 & 12,3 & 13,8 & 13,0 & \multirow{3}{*}{14,8} \\
\hline & $1 \mathrm{~N}$ & 16,8 & 15,8 & 17,0 & 16,5 & \\
\hline & $\begin{array}{c}\text { średnio } \\
\text { mean }\end{array}$ & 14,8 & 14,0 & 15,4 & - & \\
\hline \multirow{3}{*}{$\begin{array}{l}\text { Talerzowanie } \\
\text { Disking }\end{array}$} & $1 / 2 \mathrm{~N}$ & 17,3 & 12,7 & 14,4 & 14,8 & \multirow{3}{*}{15,7} \\
\hline & $1 \mathrm{~N}$ & 18,2 & 15,7 & 16,0 & 16,6 & \\
\hline & $\begin{array}{c}\text { średnio } \\
\text { mean }\end{array}$ & 17,7 & 14,2 & 15,2 & - & \\
\hline \multirow{2}{*}{$\begin{array}{l}\text { Średnio dla nawożenia } \\
\text { Mean for fertilization }\end{array}$} & $1 / 2 \mathrm{~N}$ & 17,1 & 12,9 & 15,0 & 15,0 & \multirow{2}{*}{-} \\
\hline & $1 \mathrm{~N}$ & 18,7 & 16,0 & 16,6 & 17,1 & \\
\hline \multicolumn{2}{|l|}{$\begin{array}{l}\text { Średnio dla międzyplonu } \\
\text { Mean for catch crop }\end{array}$} & 17,9 & 14,5 & 15,8 & \multicolumn{2}{|c|}{-} \\
\hline
\end{tabular}

$\operatorname{NIR}(0,05)-\operatorname{LSD}(0.05)$

I - międzyplon - catch crop; II - sposób uprawy - tillage system; III - nawożenie N - nitrogen fertilization;

I - 1,1; II - 1,1; III - 0,59; I × II - 1,30; I × III - r.n.; II × III - 0,93; I × II × III - r.n.; r.n. - różnica nieistotna - not significant difference

Tabela 2. Indeks porażenia korzeni pszenicy jarej (2011-2012)

Table 2. Infection index of spring wheat roots (2011-2012)

\begin{tabular}{|c|c|c|c|c|c|c|}
\hline \multirow[b]{2}{*}{$\begin{array}{l}\text { Sposób uprawy } \\
\text { Tillage system }\end{array}$} & \multirow{2}{*}{$\begin{array}{l}\text { Nawożenie } \\
\text { azotem } \\
\text { Nitrogen } \\
\text { fertilization } \\
{[\mathrm{kg} / \mathrm{ha}]}\end{array}$} & \multicolumn{4}{|c|}{ Międzyplon - Catch crop } & \multirow{2}{*}{$\begin{array}{c}\text { Średnio } \\
\text { dla uprawy } \\
\text { Mean } \\
\text { for tillage }\end{array}$} \\
\hline & & $\begin{array}{c}\text { brak } \\
\text { without }\end{array}$ & $\begin{array}{l}\text { gorczyca } \\
\text { mustard }\end{array}$ & $\begin{array}{l}\text { mieszanka } \\
\text { mixture }\end{array}$ & $\begin{array}{l}\text { średnio } \\
\text { mean }\end{array}$ & \\
\hline \multirow{3}{*}{$\begin{array}{l}\text { Siew bezpośredni } \\
\text { Direct seeding }\end{array}$} & $1 / 2 \mathrm{~N}$ & 19,9 & 18,6 & 22,8 & 20,4 & \multirow{3}{*}{21,0} \\
\hline & $1 \mathrm{~N}$ & 25,5 & 19,9 & 19,1 & 21,5 & \\
\hline & $\begin{array}{c}\text { średnio } \\
\text { mean }\end{array}$ & 22,7 & 19,3 & 21,0 & - & \\
\hline \multirow{3}{*}{$\begin{array}{l}\text { Orka } \\
\text { Ploughing }\end{array}$} & $1 / 2 \mathrm{~N}$ & 19,1 & 16,5 & 19,5 & 18,3 & \multirow{3}{*}{18,6} \\
\hline & $1 \mathrm{~N}$ & 21,4 & 16,1 & 19,2 & 18,9 & \\
\hline & $\begin{array}{c}\text { średnio } \\
\text { mean }\end{array}$ & 20,2 & 16,3 & 19,3 & - & \\
\hline \multirow{3}{*}{$\begin{array}{l}\text { Talerzowanie } \\
\text { Disking }\end{array}$} & $1 / 2 \mathrm{~N}$ & 21,8 & 19,3 & 16,1 & 19,1 & \multirow{3}{*}{18,1} \\
\hline & $1 \mathrm{~N}$ & 18,8 & 16,4 & 16,3 & 17,2 & \\
\hline & $\begin{array}{c}\text { średnio } \\
\text { mean }\end{array}$ & 20,3 & 17,9 & 16,2 & - & \\
\hline \multirow{2}{*}{$\begin{array}{l}\text { Średnio dla nawożenia } \\
\text { Mean for fertilization }\end{array}$} & $1 / 2 \mathrm{~N}$ & 20,2 & 18,1 & 19,4 & 19,3 & \multirow[b]{2}{*}{-} \\
\hline & $1 \mathrm{~N}$ & 21,9 & 17,5 & 18,2 & 19,2 & \\
\hline \multicolumn{2}{|l|}{$\begin{array}{l}\text { Średnio dla międzyplonu } \\
\text { Mean for catch crop }\end{array}$} & 21,1 & 17,8 & 18,8 & \multicolumn{2}{|c|}{-} \\
\hline
\end{tabular}

$\operatorname{NIR}(0,05)-\operatorname{LSD}(0.05)$

I - międzyplon - catch crop; II - sposób uprawy - tillage system; III - nawożenie N - nitrogen fertilization;

I - 0,61; II - 0,93; III - r.n.; I × II - 1,44; I × III - 0,98; II × III - 1,21; I × II × III - 1,87; r.n. - różnica nieistotna - not significant difference 
Majchrzak i Sawinska (2013) wykazali, że sposób uprawy gleby istotnie różnicował porażenie jęczmienia jarego przez sprawców fuzaryjnej zgorzeli podstawy źdźbła. Zauważyli, że płużna uprawa gleby wpływa na nasilenie choroby $\mathrm{w}$ porównaniu $\mathrm{z}$ siewem bezpośrednim, który ją ograniczał. Również w przypadku łamliwości źdźbła mniejsze porażenie występowało na obiektach z siewem bezpośrednim.

Także redukcja dawki nawożenia azotem o $60 \mathrm{~kg}$ istotnie poprawiła tę cechę, o 2,1 p.p. w porównaniu do obiektu z pełną dawką. Colbach i wsp. (1997) zauważyli, że występuje zależność między większą liczbą roślin porażonych przez zgorzel podstawy źdźbła a dawką nawozu azotowego. Na pszenicy najbardziej widoczne objawy chorobowe występowały przy najwyższym poziomie nawożenia azotowego.

Nie wykazano istotnego wpływu interakcji wszystkich badanych czynników doświadczenia na porażenie źdźbeł pszenicy.

Gorczyca biała i mieszanka roślin strączkowych poprawiły również zdrowotność korzeni pszenicy jarej w porównaniu do uprawy bez międzyplonu, a różnica ta została udowodniona statystycznie (tab. 2). Także w tym przypadku lepszą okazała się gorczyca niż mieszanka. Po międzyplonie $\mathrm{z}$ rośliny $\mathrm{z}$ rodziny Brassicaceae indeks porażenia korzeni był o 3,3 p.p., a po strączkowych o 2,3 p.p. mniejszy od wykazanego w uprawie bez międzyplonów. Podobną zależność wykazali Wojciechowski (2005, 2009) oraz Kwiatkowski (2008).

Wykazano istotne ograniczenie liczby korzeni porażonych pszenicy jarej po wiosenny talerzowaniu biomasy międzyplonu lub jego przyoraniu w porównaniu do siewu bezpośredniego w mulcz, odpowiednio o 2,9 i 2,4 p.p. Również Małecka i wsp. (2011) wykazali, że systemy bezorkowej uprawy powodują większe porażenie jęczmienia jarego przez patogeny źdźbła i korzeni.

Redukcja dawki nawożenia azotem nie miała większego wpływu na kształtowanie zdrowotności korzeni pszenicy jarej. Piekarczyk i Lemańczyk (2013) odnotowali natomiast, że wraz ze wzrostem dawki nawożenia azotowego zwiększało się nasilenie występowania chorób pszenicy ozimej.

Istotne oddziaływanie na tę cechę miało współdziałanie wszystkich czynników badań. Najmniejsze porażenie korzeni stwierdzono $\mathrm{w}$ uprawie pszenicy po międzyplonie z mieszanki roślin strączkowych, jego wiosennym talerzowaniu i stosowaniu połowy dawki nawożenia $\mathrm{N}$, a najwyższe w siewie bezpośrednim, bez międzyplonu i stosowaniu pełnej dawki azotu.

\section{Wnioski / Conclusions}

1. Międzyplony ścierniskowe ograniczyły liczbę źdźbeł oraz korzeni pszenicy jarej porażonych przez patogeny.

2. Rośliną międzyplonową $\mathrm{w}$ większym stopniu poprawiającą zdrowotność pszenicy jarej była gorczyca biała niż mieszanka roślin strączkowych.

3. Korzystniejszym, pod względem zdrowotności pszenicy, sposobem wiosennego zagospodarowania międzyplonu było jego wymieszanie $\mathrm{z}$ glebą przez orkę lub talerzówkę niż pozostawienie go jako mulcz.

4. Najmniejszy indeks porażenia korzeni stwierdzono $\mathrm{W}$ uprawie pszenicy po międzyplonie $\mathrm{z}$ mieszanki roślin strączkowych, jego wiosennym talerzowaniu i stosowaniu połowy dawki nawożenia $\mathrm{N}$, a najwyższe w siewie bezpośrednim, bez międzyplonu i stosowaniu pełnej dawki azot.

\section{Literatura / References}

Arvidsson J. 1998. Effects of cultivation depth in reduced tillage on soil physical properties, crop yield and plant pathogens. European Journal of Agronomy 9: 79-85.

Bailey K.L., Mortensen K., Lafond G.P. 1992. Effects of tillage systems and crop rotations on root and foliar diseases of wheat, flax, and peas in Saskatchewan. Canadian Journal of Plant Science 72: 583-591.

Blecharczyk A., Małecka I., Skrzypczak G., Pudełko J. 2000. Wpływ grochu jako rośliny regenerującej na występowanie chorób i plonowanie pszenicy ozimej w różnych systemach uprawy roli. Zeszyty Problemowe Postępów Nauk Rolniczych 470: 13-19.

Borkowska H., Grundas S., Styk B. 2002. Wysokość i jakość plonów niektórych odmian pszenicy jarej w zależności od nawożenia azotowego. Annales Universitatis Mariae Curie-Skłodowska, Sectio E, Agricultura 7: 99-103.

Colbach N., Lucas P., Meynard J.M. 1997. Influence of crop management on take-all development and disease cycles on winter wheat. Phytopathology 87 (1): 26-32.

Dworakowski T. 1998. Działanie międzyplonu ścierniskowego w ogniwie zmianowania zboża ozime-zboża jare. Fragmenta Agronomica 15 (3): 90-99.

Faltyn U., Kordas L. 2009. Wpływ różnych systemów uprawy roli oraz zróżnicowanego nawożenia fosforowo-potasowego na zdrowotność pszenicy jarej. [The effect of varying tillage system and different phosphorus and potassium fertilization on health status of spring wheat]. Progress in Plant Protection/Postępy w Ochronie Roślin 49 (1): 393-396.

Gawęda D., Haliniarz M. 2013. Plonowanie i zachwaszczenie owsa siewnego (Avena sativa L.) uprawianego w monokulturze w zależności od sposobu odchwaszczania i międzyplonu. [Yielding and weed infestation of oats (Avena sativa L.) grown in monoculture depending on weed control method and stubble catch crop]. Progress in Plant Protection/Postępy w Ochronie Roślin 53 (2): 297-302.

Harasim E., Gawęda D. 2010. Wpływ międzyplonów ścierniskowych na plonowanie i efektywność energetyczną produkcji zbóż jarych. Annales Universitatis Mariae Curie-Skłodowska, Sectio E, Agricultura 65 (1): 64-72.

Jaskulska I., Gałęzewski L. 2009. Aktualna rola międzyplonów w produkcji roślinnej i środowisku. Fragmenta Agronomica 26 (3): $48-57$.

Kwiatkowski C. 2008. Architektura łanu i zdrowotność jęczmienia jarego uprawianego w monokulturze w zależności od regeneracyjnego wpływu międzyplonu. Fragmenta Agronomica 25 (1): 199-209. 
Majchrzak L., Sawinska Z. 2013. Wpływ sposobu uprawy gleby, przedplonu i rodzaju pozostawionej biomasy na porażenie jęczmienia jarego przez grzyby chorobotwórcze. [Influence of soil tillage system, forecrop and kind of crop residue on spring barley infection by pathogenic fungi]. Progress in Plant Protection/Postępy w Ochronie Roślin 53 (1): 132-137.

Małecka I., Blecharczyk A., Sawinska Z., Dytman-Hagedon M. 2011. Zdrowotność jęczmienia jarego w bezorkowych systemach uprawy roli. [Health status of spring barley in ploughless tillage systems]. Progress in Plant Protection/Postępy w Ochronie Roślin 51 (2): 867-871.

Narkiewicz-Jadko M., Gil Z., Wojciechowski W., Żmijewski M. 2008. Zdrowotność i jakość ziarna pszenicy jarej w zależności od międzyplonu i nawożenia azotem. Fragmenta Agronomica 25 (1): 251-260.

Orzech K., Marks M., Dragańska E., Stępień A. 2009. Plonowanie pszenicy ozimej w zależności od warunków pogodowych i różnych sposobów uprawy gleby średniej. Annales Universitatis Mariae Curie-Skłodowska, Sectio E, Agricultura 64 (4): $122-129$.

Piekarczyk M., Lemańczyk G. 2013. Wpływ nawożenia azotem na zdrowotność wybranych odmian pszenicy ozimej uprawianych na glebie lekkiej. [Effect of nitrogen fertilization on health status of some winter wheat cultivars grown on light soil]. Progress in Plant Protection/Postępy w Ochronie Roślin 53 (3): 494-497.

Pląskowska E. 2005. Zdrowotność pszenicy jarej uprawianej w siewie czystym i w mieszaninach odmian. Zeszyty Naukowe Akademii Rolniczej we Wrocławiu. Rozprawy CCXXXVI Rolnictwo 528: 1-142.

Townsend G.R., Heuberger J.W. 1943. Methods for estimating losses caused by diseases in fungicide experiments. Plant Disease Report 27: $340-343$.

Weber R., Hryńczuk B., Runowska-Hryńczuk B., Kita W. 2001. Influence of the mode of tillage on diseases of culm base in some winter wheat varieties, oats and spring wheat. Journal of Phytopathology 149: 185-188.

Wojciechowski W. 2005. Oddziaływanie przyorywanych międzyplonów ścierniskowych i nawożenia azotem na zdrowotność roślin pszenicy jakościowej. [The influence of plowed down stubble crops and nitro gen fertilization on health of quality wheat]. Progress in Plant Protection/Postępy w Ochronie Roślin 45 (2): 1197-1199.

Wojciechowski W. 2008. Następczy wpływ międzyplonów ścierniskowych na zdrowotność pszenicy uprawianej w krótkotrwałej monokulturze. [Aftercrop effect of stubble intercrops on health status of wheat growing in short-term monoculture]. Progress in Plant Protection/Postępy w Ochronie Roślin 48 (1): 381-384.

Wojciechowski W. 2009. Znaczenie międzyplonów ścierniskowych w optymalizacji nawożenia azotem jakościowej pszenicy jarej. Wydawnictwo Uniwersytetu Przyrodniczego we Wrocławiu, 122 ss. 